choice; though here, also, he leans overmuch to the linguistic side.

In the curriculum of studies recommended by him, Mr. Fitch has strangely subordinated, if he has not greatly ignored, the studies that prepare the citizen for his duties as a member of the State-the Social and Political Sciences. Surely he has not read, or greatly studied, the admirable pleading in their favour to be found in the works of his friend William Ellis, and also of George Combe, as recently fully presented in his educational contributions, edited by one of his colleagues in the inspectorate. In this respect, there appears to us to exist a serious hiatus in his plan of study. One of the doctrines be enunciates is also enough to raise the old phrenologist from his grave, what he calls "the convertibility of intellectual forces," whereby, he informs us, "every kind of mental power, once worked and applied to a worthy purpose, becomes available for other purposes, and is capable of being trans. formed into power of another kind"-an ancient error in schools, still fruitful of failure and wrong, which we are surprised to find held by a man so generally wise on education. Poor George Combe otherwise fares sadly at the hands of Mr. Fitch, who describes his mission in life as being that of advocating the one doctrine of inherent hereditary aptitudes, and says that "he never could induce his friends seriously to attempt the classification and teaching of a school on his principles, and the experiment yet remains untried"! What of the history of such schools given in the work on Combe's principles just named?

Though not agreeing on many points with the author, as was inevitable in a field so full of controversial matter as the growing science of education, we look upon the book as a valuable contribution to the subject, which, by its unusually attractive style and high tone, will command a wide audience, and, from the auspices under which it is produced, will reach places where sound educational philosophy too seldom penetrates. We cordially recommend it to all interested in education, and specially to teachers; and also to the active Education Society, as, like Prof. Bain's recent work on Education, which they have already taken up, an admirable basis of profitable discussion.

\section{PRACTICAL HISTOLOGY}

A Text-Book of Practical Histology, with Outline Plates. By W. Stirling, M.D., Sc.D., F.R.S.E., Regius Professor of the Institutes of Medicine in the University of Aberdeen. (London: Smith, Elder and Co., 1881.)

A $\mathrm{T}$ the outset Dr. Stirling informs us that "the purpose A of this work is twofold : first, to give plain, definite, and precise directions for the preparation and examination of the animal tissues; and secondly, to ensure that the student executes a drawing of the majority of the microscopic specimens which he makes for preservation. For this purpose a series of Outline Plates is issued with the text."

As regards the first of these objects, there is no doubt that to give "plain, definite, and precise directions" is a desirable and praiseworthy object, which most, if not all "practical" books strive to attain. Those that sueceed in this endeavour differ from one another chiefly in the means by which this object is accomplished; in some the author arrives at his object after long-continued patient and diligent work, in other rarer instances he utilises the works of others, and by doing so he may, and sometimes actually does, produce a book which has considerable merits of its own, inasmuch as it gives in plain and simple words valuable and useful extracts of much larger original works full of minute and bewildering details, not easily understood by, and of little practical use to the ordinary student. Dr. Stirling, although his book cannot in any sense claim to be considered other than a book of compilation, has nevertheless succeeded in presenting to the medical student, anxious to acquire the necessary amount of knowledge in practical histology, a work which, conveying in a short and intelligible manner a great deal of information, will, we doubt not, prove of service.

As regards the second object of the book, viz. that the student should for himself make drawings of his microscopic specimens, we fail to see how Dr. Stirling's Outline Plates can advance this object in a satisfactory manner. We always thought that the student drawing the correct outlines of the specimens or of parts of the specimens prepared by himself, has got everything that is essential to guide him in the study of those specimens. To fill in the details in pencil, or, as Dr. Stirling suggests, and what is still more laborious, in colours, in the outline figures drawn for him from somebody else's specimens, appears to us of more than questionable value.

Besides the directions for practical work a considerable part of the book is taken up by the description of the structure of the simple tissues and organs. As far as we can see, these descriptions are in a great measure, to the extent of verbal quotations, borrowed from other books, without even an attempt to mention this fact; by doing so Dr. Stirling has deviated from the accustomed rule, and has proceeded in a rare and unexpected manner. If an author introduces abstracts and verbal quotations from any other work, we believe it will be universally admitted that whatever the aim and nature of the book, the author is bound to mention his source; if he omits to do this, intentionally or unintentionally, he lays himself open to the charge of having committed what in the eyes of every right-thinking mar, not to say of every man of science and teacher in a responsible position, must ever be considered a grave offence.

Dr. Stirling has made very extensive use of the "Atlas of Histology" in some chapters, e.g. on the salivary glands, the kidneys, the generative organs, and others, making copious extracts therefrom, to the extent of verbal quotations, without in any way indicating that he has done so.

Dr. Stirling's proceeding is greatly to be regretted, since by his numerous and original works in histology he has won the esteem of his confrères and has proved himself to be sincerely anxious about the promotion of this science.

The publishers deserve great credit for the handsome style in which the book is brought out.

E. KLEIN 